\title{
Effect of Vitamin A Supplementation, Cooking Oil Fortification, and Nutrition Education to Postpartum Mother on Breast Milk Retinol Levels
}

\author{
Abdul Salam $^{1 *(1 D}$, Dodik Briawan² ${ }^{2}$, Drajat Martianto ${ }^{2}$, Abdul Razak Thaha $^{1}$, Devintha Virani ${ }^{1}$ \\ ${ }^{1}$ Departement of Nutrition, Faculty of Public Health, Hasanuddin University, Makassar, Indonesia; ${ }^{2}$ Departement of Community \\ Nutrition, Faculty of Human Ecology, Bogor Agricultural University, Bogor, Indonesia
}

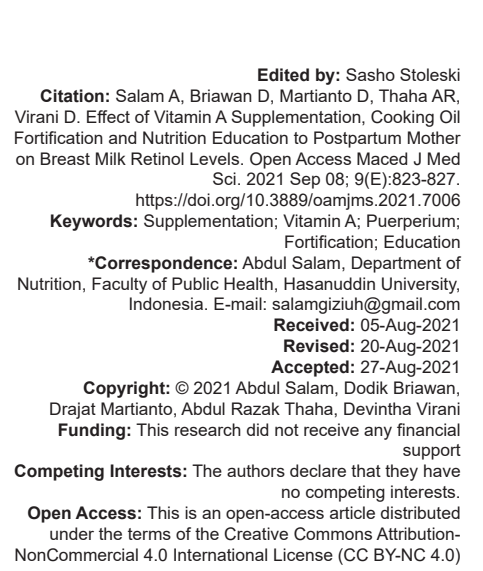

\section{Abstract}

AIM: The study aims to determine the effect of two forms of Vitamin A supplementation (dose of $2 \times 200000 \mathrm{IU}$ and dose of $1 \times 200000 \mathrm{IU}$ ), Vitamin A fortified cooking oil and nutritional education on retinol levels of breast milk.

METHODS: A quasi-experiment design was used in this study with a total of 129 subjects divided into four groups Group A (given 2 capsule of Vitamin A), Group B (given 1 capsule of Vitamin A), Group C (given cooking oil fortification), and Group D (given nutritional education). Retinol levels of the breast milk were measured 3 times (before, during, and after intervention).

RESULTS: There were no differences in subject characteristics in terms of age, education, occupation, parity, and nutritional status between intervention groups $(p>0.05)$. The average of breast milk retinol levels was $52.15 \mu \mathrm{g} / \mathrm{d}$ at the beginning. At the end of the measurement, the average decrease in breast milk retinol levels was higher in Group D $(-27.2 \mu \mathrm{g} / \mathrm{dl})$, and the lowest was in Group C $(-9.9 \mu \mathrm{g} / \mathrm{dl})$. The results of statistical tests showed that there was no difference in breast milk retinol levels between intervention groups in before, during, and after the intervention $(p>0.05)$.

CONCLUSIONS: Fortified cooking oil and Vitamin A supplementation $(1 \times 200000 \mathrm{IU})$ tend to maintain normal levels of retinol in breast milk compared to Vitamin A supplementation $(2 \times 200000 \mathrm{IU})$ and nutrition education.

\section{Introduction}

Deficiency of Vitamin A is commonly found in pregnant women, children, and postpartum mothers. It affects 19 million pregnant women and an estimated of 1000 pregnant women ends up in death, also there are complications for children born around the world every day [1]. Vitamin A status in most newborns, including marginal status [2], [3], [4]. [5] and the baby's chance of experiencing Vitamin A deficiency is increasing as their mother have an inadequate intake of Vitamin A. Such condition in babies may be overcome by providing breast milk which contains an adequate concentration of retinol that influenced by nutritional status and intake of the mother [3]. To increase retinol in breast milk, supplementation of Vitamin A to nursing mother has been proposed as an alternative strategy to increase Vitamin A's intake for breastfed infants exclusively until the age of 6 months [6].

In 2011, the World Health Organization issued a recent recommendation that supplementation of high doses of Vitamin A to postpartum mothers shortly after give a birth was not needed anymore due to its insignificant effect both on morbidity and mortality of mothers and babies aged 0-6 months [1]. The WHO also expects in the guidelines that study of the effects of high doses of Vitamin A supplementation (200000 SI) at $6^{\text {th }}$ week after mother gives a birth should be done in the future as an alternative to supplementation shortly after delivery.

The $\mathrm{WHO}$, in the latest recommendations related to supplementation of Vitamin A, recommends that postpartum mothers should be encouraged to obtain adequate and balanced nutrition [1]. Consumption of fruits and vegetables, especially those containing Vitamin A can also be one alternative to meet the needs of Vitamin A in postpartum mothers. Unfortunately, results of baseline health research 2013 show that around $93.5 \%$ of people aged $\geq 10$ years old are lack in consuming fruits and vegetables [7]. Therefore, it needs communication, information, and education efforts to increase consumption of food sources of Vitamin A which come from fruits and vegetables, especially during pregnancy and when mothers are breastfeeding as well.

In some developing countries, food consumption is usually more monotonous and generally based on cereals and legumes which are usually low in 
Vitamin A. To overcome this situation, food fortification is done to increase daily intake of Vitamin A [8]. One type of food considered to be quite potential and meet the requirements for fortification is cooking oil. Results of study in Tasikmalaya and Ciamis districts show that fortified cooking oil with $45 \mathrm{SI}$ retinol/g has increased retinol levels of breastfeeding mothers from $20.5 \mu \mathrm{g} /$ $\mathrm{dl}$ at baseline to $32.5 \mu \mathrm{g} / \mathrm{dl}$ at end line [9]. This study investigated the effects of giving two forms of Vitamin A supplementation $(2 \times 200000$ SI dose and $1 \times 200000$ SI dose), giving fortification of Vitamin A in cooking oil, and nutritional education on breast milk retinol levels.

\section{Materials and Methods}

\section{Study design and site}

The research used a quasi-experiment design. This research was carried out in seven public health center (Puskesmas) in Gowa district, South Sulawesi Province, Indonesia from June 2017 to March 2018.

\section{Sample}

Subjects in this study were postpartum mothers in working area of Gowa District's Public Health Center selected based on criteria; (1) giving birth normally and at exact month, (2) normal birth weight, and (3) maximum $3^{\text {rd }}$ parity. The minimum number of subjects needed for this study was calculated using mean different hypothesis test formula with $80 \%$ test strength and $5 \%$ significance, an average standard deviation of breast milk retinol levels is $10 \mu \mathrm{g} / \mathrm{dl}$ and an average difference of breast milk retinol levels is $7.2 \mu \mathrm{g} / \mathrm{dl}$. Based on calculation results, a minimum number of subjects for each treatment group is 24 people. There were four treatment groups, which meant the minimum number of subjects in this study was 96 people. At the beginning of the study, as much as 160 subjects were met the criteria, but at the end only 129 of postpartum mothers could be analyzed, while the rest of the subjects were drop out because they moved to another area (two people) or they did not have breast milk in the $2^{\text {nd }}$ and $3^{\text {rd }}$ collected of the sample (29 people).

\section{Intervention}

There were four treatment groups in this study, they were Group A who received 2 tablets of Vitamin A $200000 \mathrm{SI}$ dose, Group B received 1 tablet of Vitamin A 200000 SI dose, Group C received Vitamin A fortification in cooking oil, and Group D educated about nutrition and health.

Group A was given two tablets of Vitamin A 200000 SI dose which consumed in 2 steps. The first tablet was given right after the mother gave a birth, and the second tablet was given minimum $24 \mathrm{~h}$ after the first tablet. Breast milk sample was taken before consuming the first tablet of Vitamin A.

Meanwhile, Group B was given 1 tablet of Vitamin A 200000 SI dose on the $6^{\text {th }}$ month after the mother gave a birth which was administrated by enumerator when they visited the mother's house. Yet, interviewing and collecting the first breast milk sample was done on day-3 after gave a birth.

As for Group C, they were given cooking oil fortified with Vitamin A for 3 months after gave a birth. Distribution was done along with collected baseline data. Subjects were given 1 I of cooking oil every week to consume for 12 weeks ( 3 months). The oil was a branded manufacturer oil that has been fortified with 62 SI of retinil palmitate.

Finally, it was Group D which was educated for 5 times that divided into two stages. Firstly was divided into two sessions when the subjects were pregnant, secondly was a moment when the subjects gave a birth (especially postpartum) for 3 times. Educating pregnant mothers was done in a group (15 pregnant mothers maximum) using pocket book and power point that has been arranged by researcher team for about 30-60 min. Educating postpartum mothers was done by visiting the subjects' houses and using leaflet containing information about Vitamin A consumption during postpartum moment and how vital is exclusive breast milk for infants. The first visiting was done in day-3 after the subject gave a birth (along with step 1 of collecting breast milk sample), the second was given in week 2-4, and the third was in week 5-6 after gave birth. Each stages took for about 10-15 min, focusing on food sources of Vitamin A, consuming Vitamin A during pregnancy and breastfeeding is essential, impact of Vitamin A deficiency, how to breastfeeding infant, and how to keep healthiness after bring forth.

\section{Data collection}

Data of subjects' characteristics were age of mother, parity, education, and employment, while characteristics of babies born were collected in this study using structured questionnaire. Food consumption's data collected were nutrition daily intake (protein, fat, Vitamin A, zinc, and iron) by $2 \times 24 \mathrm{~h}$ recall method (represents work day and off day). This method was done before intervention (after gave birth) and after intervention. Anthropometry measurement done in this study was body weight and height of postpartum mothers. Body weight was measured by using digital scale with $0.1 \mathrm{~kg}$ accuracy, while body height measured using microtoise with $0.1 \mathrm{~cm}$ accuracy.

Breast milk sample of postpartum mothers collected 3 times, which were: After birth (before intervention), a month after birth (during intervention), 
and 3 months after birth (after intervention). The breast was cleaned first using a wet cloth before breast milk was taken as a sample. Breast milk was not taken from the breast that still full, but from the one that has not been touched by the infant for at least $30 \mathrm{~min}$. The sample was taken only at the time between 09.00 and 12.00 a.m using manual pump as much as 3 and $5 \mathrm{ml}$ [10]. It then placed in a vial tube and wrapped up with aluminum foil before labeled with respondent's code and date of taken. The tube was stored in refrigerator at $20^{\circ} \mathrm{C}$. Levels of retinol in breast milk was analyzed using high performance liquid chromatography method [11]. This was done in Laboratory of Gizi Terpadu Badan Penelitian dan Pengembangan Kesehatan in Bogor.

\section{Data analysis}

Data were processed and analyzed using SPSS program for windows. Subject characteristics analyzed using Kruskal-Wallis to know differences in the proportion of subject characteristics between Groups A, B, C, and D. Anthropometry results were used to calculate body mass index (BMI) of breastfeeding mothers using this formula: Body weight (in $\mathrm{kg}$ ) divided with body height square (in $\mathrm{m}$ ). This $\mathrm{BMI}$ result reflected nutritional status of breast feeding mothers. Category of BMI was wasting $\left(<18.5 \mathrm{~kg} / \mathrm{m}^{2}\right)$, normal $\left(18.5-24.9 \mathrm{~kg} / \mathrm{m}^{2}\right)$, overweight $\left(25-26.9 \mathrm{~kg} / \mathrm{m}^{2}\right)$, and obese $\left(\geq 27 \mathrm{~kg} / \mathrm{m}^{2}\right)$.

Nutrient intake and levels of adequacy of the subject's nutritional intake from the results of $2 \times$ $24 \mathrm{~h}$ recall processed using Table of Indonesian Food Composition of 2017. The results then compared to recommended dietary allowances (RDA) of 2013. Normality test was done to ensure the normality of data distribution. Some numerical data such as levels of nutritional RDA and levels of retinol in breast milk analyzed using Analysis of variance (ANOVA) to identify the average differences of variables $A, B, C$, and D. ANOVA test results continued with Duncan test. To identify average differences of levels of adequate intake of nutrients before and after intervention, paired sample t test used in this study. To adjust confounder variable to the amount of difference of retinol levels in breast milk after intervention, for instance (1) retinol levels of breast milk before intervention, (2) retinol levels during intervention, and (3) adequate levels of intake of protein, fat, Vitamin A, zinc, and iron, researchers was using ANCOVA test.

\section{Results}

The Kruskal-Wallis results on Table 1 show that there were no significant differences of subject's characteristics in each treatment group ( $p>0.05)$.
Subjects aged 26-35 years old was higher in proportion $(56.6 \%)$ compared to those aged $20-25$ years old $(43.4 \%)$. As for levels of education, subjects graduated from high school as much as $40.3 \%$, and most of the postpartum mothers in this study did not work (housewives) (93.8\%). In parity level, 76\% subjects were in the multipara category (parity $\geq 2$ ). Results of BMI measurements show that normal nutritional status of postpartum mothers identified as much as $60.5 \%$, this is dominating compared to wasting, overweight, and obesity.

Table 1: Distribution of subject in group based on characteristics

\begin{tabular}{|c|c|c|c|c|c|c|}
\hline \multirow[t]{4}{*}{ Variable } & \multicolumn{4}{|c|}{ Intervention groups } & \multirow[t]{2}{*}{ Total } & \multirow[t]{4}{*}{$\mathrm{p}$} \\
\hline & $\mathrm{A}$ & $\mathrm{B}$ & C & $\mathrm{D}$ & & \\
\hline & $n=29$ & $n=36$ & $n=29$ & $n=35$ & $n=129$ & \\
\hline & $n(\%)$ & $\mathrm{n}(\%)$ & $\mathrm{n}(\%)$ & $\mathrm{n}(\%)$ & $\mathrm{n}(\%)$ & \\
\hline \multicolumn{7}{|l|}{ Age } \\
\hline $20-25$ y.o & $11(37.9)$ & $15(41.7)$ & $14(48.3)$ & $16(45.7)$ & $56(43.4)$ & \multirow[t]{2}{*}{0.748} \\
\hline $26-35$ у.о & $18(62.1)$ & $21(58.3)$ & $15(51.7)$ & $19(54.3)$ & $73(56.6)$ & \\
\hline \multicolumn{7}{|l|}{ Education } \\
\hline Primary School & $10(34.5)$ & $9(25.0)$ & $8(27.6)$ & $11(31.4)$ & $38(29.5)$ & \multirow[t]{4}{*}{0.941} \\
\hline Junior School & $4(13.8)$ & $7(19.4)$ & $10(34.5)$ & $8(22.9)$ & $29(22.5)$ & \\
\hline Senior School & $11(37.9)$ & $20(55.6)$ & $7(24.1)$ & $14(40.0)$ & $52(40.3)$ & \\
\hline Diploma/Bachelor & $4(13.8)$ & $0(0)$ & $4(13.8)$ & $2(5.7)$ & $10(7.8)$ & \\
\hline \multicolumn{7}{|l|}{ Occupation } \\
\hline Unemployment/ & $27(93.1)$ & $33(91.7)$ & $27(93.1)$ & $34(97.1)$ & $121(93.8)$ & \multirow[t]{3}{*}{0.803} \\
\hline Housewife & & & & & & \\
\hline Working & $2(6.9)$ & $3(8.3)$ & $2(6.9)$ & $1(2.9)$ & $8(6.2)$ & \\
\hline \multicolumn{7}{|l|}{ Parity } \\
\hline Primipara & $6(20.7)$ & $8(22.2)$ & $10(34.5)$ & $7(20.0)$ & $31(24.0)$ & \multirow[t]{2}{*}{0.518} \\
\hline Multipara & $23(79.3)$ & $28(77.8)$ & $19(65.5)$ & $28(80.0)$ & $98(76.0)$ & \\
\hline \multicolumn{7}{|l|}{ Nutritional status } \\
\hline Wasting $(<18.5)$ & $4(13.8)$ & $4(11.1)$ & $2(6.9)$ & $2(5.7)$ & $12(9.3)$ & \multirow[t]{4}{*}{0.823} \\
\hline Normal ( $\geq 18.5-24.9)$ & $15(51.7)$ & $23(63.9)$ & $18(62.1)$ & $22(62.9)$ & 78 (60.5) & \\
\hline Overweight ( $\geq 25.0-26.9)$ & $6(20.7)$ & $6(16.7)$ & $5(17.2)$ & $6(17.1)$ & $23(17.8)$ & \\
\hline Obesity $(\geq 27.0)$ & $4(13.8)$ & $3(8.3)$ & $4(13.8)$ & $5(14.3)$ & $16(12.4)$ & \\
\hline
\end{tabular}

Table 2 shows the average levels of adequate intake of after and before interventions. Before intervention illustrates that almost all of nutritional intake of subjects between treatment groups were different $(p<0.05)$, except for zinc intake ( $p>0.05)$. The nutrients intake experienced downward trends in all intervention groups unless for Vitamin A in Group C which shows an increase.

Table 2: Adequacy level of nutrients intake of subjects based on groups before and after intervention

\begin{tabular}{|c|c|c|c|c|c|c|}
\hline \multirow[t]{3}{*}{ Nutrients } & \multirow[t]{3}{*}{ Time } & \multicolumn{4}{|c|}{ Groups of intervention } & \multirow[t]{3}{*}{$p^{11}$} \\
\hline & & A & $\mathrm{B}$ & C & D & \\
\hline & & Mean \pm SD & Mean \pm SD & Mean \pm SD & $\overline{M e a n} \pm \mathrm{SD}$ & \\
\hline \multirow[t]{3}{*}{ Protein (\%) } & Before & $72.8 \pm 0.16^{\mathrm{a}}$ & $99.4 \pm 0.12^{b}$ & $75.8 \pm 0.12^{\mathrm{a}}$ & $78.7 \pm 0.16^{\mathrm{a}}$ & $0.000^{*}$ \\
\hline & After & $49.9 \pm 0.13^{\mathrm{a}}$ & $62.8 \pm 0.13^{b}$ & $50.5 \pm 0.14^{\mathrm{a}}$ & $66.7 \pm 0.15^{\mathrm{b}}$ & $0.001^{*}$ \\
\hline & $p^{2)}$ & $0.000^{*}$ & $0.000^{*}$ & $0.000^{*}$ & $0.042^{*}$ & \\
\hline \multirow[t]{3}{*}{ Lipid (\%) } & Before & $47.6 \pm 0.28^{\mathrm{a}}$ & $72.1 \pm 0.21^{b}$ & $68.3 \pm 0.22^{b}$ & $49.7 \pm 0.31^{a}$ & $0.001^{\star}$ \\
\hline & After & $26.8 \pm 0.24^{\mathrm{a}}$ & $36.7 \pm 0.12^{b}$ & $32.7 \pm 0.26^{b}$ & $43.0 \pm 0.29^{\mathrm{ab}}$ & $0.021^{*}$ \\
\hline & $p^{2)}$ & $0.003^{*}$ & $0.000^{*}$ & $0.000^{*}$ & 0.634 & \\
\hline \multirow[t]{3}{*}{ Vitamin A (\%) } & Before & $53.5 \pm 0.24^{\mathrm{a}}$ & $67.7 \pm 0.15^{b}$ & $46.7 \pm 0.24^{\mathrm{a}}$ & $58.5 \pm 0.27^{\mathrm{ab}}$ & $0.004^{*}$ \\
\hline & After & $39.8 \pm 0.34^{a}$ & $60.5 \pm 0.32^{b}$ & $59.8 \pm 0.19^{b}$ & $38.9 \pm 0.37^{\mathrm{a}}$ & $0.000^{\star}$ \\
\hline & $p^{2)}$ & $0.042^{*}$ & 0.233 & $0.030^{\star}$ & $0.001^{*}$ & \\
\hline \multirow[t]{3}{*}{ Zinc (\%) } & Before & $32.8 \pm 0.14^{\mathrm{a}}$ & $40.5 \pm 0.15^{b}$ & $38.5 \pm 0.18^{\mathrm{ab}}$ & $37.1 \pm 0.18^{\mathrm{ab}}$ & 0.100 \\
\hline & After & $22.5 \pm 0.13^{\mathrm{a}}$ & $29.4 \pm 0.12^{b}$ & $25.2 \pm 0.14^{\mathrm{ab}}$ & $28.6 \pm 0.15^{\mathrm{b}}$ & $0.000^{*}$ \\
\hline & $p^{2)}$ & $0.000^{*}$ & $0.000^{*}$ & $0.000^{*}$ & $0.009^{*}$ & \\
\hline \multirow[t]{3}{*}{ Iron (\%) } & Before & $38.0 \pm 0.20^{\mathrm{a}}$ & $63.3 \pm 0.24^{b}$ & $37.1 \pm 0.19^{\mathrm{a}}$ & $46.0 \pm 0.22^{\mathrm{a}}$ & $0.000^{*}$ \\
\hline & After & $35.8 \pm 0.18^{a}$ & $29.8 \pm 0.21^{\mathrm{a}}$ & $28.9 \pm 0.19^{\mathrm{a}}$ & $33.1 \pm 0.18^{\mathrm{a}}$ & 0.785 \\
\hline & $p^{2)}$ & 0.811 & $0.000^{*}$ & 0.317 & 0.169 & \\
\hline
\end{tabular}

The subjects' average retinol level before treatment was $52.15 \mu \mathrm{g} / \mathrm{dl}$ and the highest score was found in D group as much as $61.25 \mu \mathrm{g} / \mathrm{dl}$ (Table 3). ANOVA test results show no significant differences at the time before, during, and after interventions, similar case happened for differences of average retinol levels of breast milk between intervention groups $(0>0.05)$. 
Table 3: Breast milk retinol levels of subjects based on group before, during, and after 3 months intervention

\begin{tabular}{|c|c|c|c|c|c|}
\hline \multirow{3}{*}{$\begin{array}{l}\text { Breast milk } \\
\text { Retinol }(\mu \mathrm{g} / \mathrm{dl})\end{array}$} & \multicolumn{4}{|c|}{ Intervention Group } & \multirow[t]{3}{*}{$\mathrm{p}^{t)}$} \\
\hline & A & B & C & D & \\
\hline & Mean \pm SD & Mean \pm SD & Mean \pm SD & Mean \pm SD & \\
\hline Before & $52.75 \pm 0.21^{\text {at }}$ & $46.22 \pm 0.21^{\mathrm{at}}$ & $47.94 \pm 0.25^{\text {at }}$ & $61.25 \pm 0.17^{\text {at }}$ & 0.062 \\
\hline During & $44.09 \pm 0.20^{\mathrm{a} 2}$ & $42.08 \pm 0.22^{\mathrm{a} 1}$ & $41.01 \pm 0.19^{\mathrm{a} 1}$ & $33.74 \pm 0.24^{\mathrm{a} 2}$ & 0.154 \\
\hline After & $34.32 \pm 0.34^{\mathrm{a} 3}$ & $32.24 \pm 0.28^{\mathrm{a} 1}$ & $38.00 \pm 0.19^{\mathrm{a} 1}$ & $33.99 \pm 0.19^{\mathrm{a} 2}$ & 0.720 \\
\hline Difference & $-18.4 \pm 0.51^{\mathrm{a}}$ & $-13.9 \pm 0.58^{\mathrm{a}}$ & $-9.9 \pm 0.51^{\mathrm{a}}$ & $-27.2 \pm 0.44^{\mathrm{a}}$ & 0.087 \\
\hline$p^{t+1}$ & $0.010^{*}$ & 0.187 & 0.110 & $0.000^{*}$ & \\
\hline \multicolumn{6}{|c|}{$\begin{array}{l}\text { SD: Standar Deviation, }{ }^{*} \text { Significant on } p<0.05 . p^{\text {ta) }} \text { ANOVA between Group A, B, C, and D, the same letter on } \\
\text { the same line indicates that there is no significant difference on } p>0.05 \text {. } p^{+t 11} \text { ANOVA between before, during } \\
\text { and after intervention, the same number on the same column indicates there is no significant difference on } \\
p>0.05 \text {. Difference: Retinol levels after deducting before. Results from adjusted with retinol levels before } \\
\text { during, and adequacy level of nutrients (protein, lipid, Vitamin A, zinc, and iron) using ANCOVA test showed } \\
\text { insignificant ( } p>0.05 \text { ). }\end{array}$} \\
\hline
\end{tabular}

A significant reducing on retinol levels of breast milk was also found after intervention in $A$ and $D$ groups $(p<0.05)$, but this was not found in B and $C$ groups $(p>0.05)$. Figure 1 shows that subject with normal category $(>30 \mu \mathrm{g} / \mathrm{dl})$ of breast milk retinol levels before intervention was higher rather than low category (found in all intervention groups).

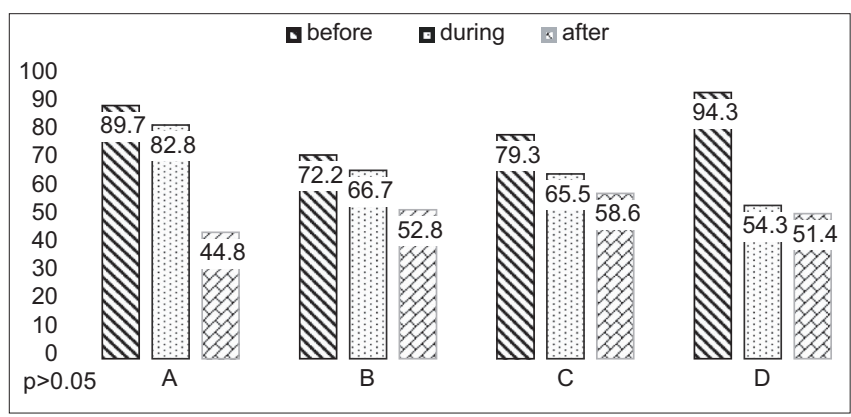

Figure 1: Percentages of subjects with normal category of breast milk retinol levels before, during, and after 3 months of interventions

\section{Discussion}

In this study, it was found that there were no differences of breast milk retinol levels between intervention groups at the time before, during, and after intervention. Moreover, it also known that subjects given fortified cooking oil has higher retinol levels rather than other groups after intervention. This is similar to a study conducted by Sandjaja et al. who found that giving cooking oil at baseline became $32.5 \mu \mathrm{g} / \mathrm{dl}$ at end line [9].

ANOVA results show no significant differences of retinol levels of breast milk at the time before (0 month), during (1 month), and after (3 months) interventions, it is similar to the difference (decreasing) between intervention groups $(p>0.05)$. It means that intervention such as high dosage of Vitamin $A$ supplementation ( 2 capsules and 1 capsule), fortified cooking oil, or nutritional education has similar effect on breast milk retinol levels. Other studies by Bezerra et al. [12] and Tomiya et al. [13] show that consumption of 2 capsules and 1 capsule of Vitamin A did not have a differences on retinol levels between groups for 1 month and 4 months of interventions.
Theoretically, retinol levels in breast milk will decrease as the infant is growing [14]. This study shows a decreasing average levels of breast milk retinol in all intervention groups, whether 1 month or 3 months after mother's gave birth. Nevertheless, the levels were still categorized as normal $(>30 \mu \mathrm{g} / \mathrm{dl})$. When they were analyzed based on the groups (intragroup), a significant decrease of retinol levels are shown at the time before, during, and after interventions in $A$ and $D$ groups ( $p<$ 0.05) (Table 3). It does not identified in B and C Groups $(p>0.05)$. This might happen in Group $B$ due to the supplementation of Vitamin A was done in $6^{\text {th }}$ week after gave birth, or because of the average intake of nutrition before treatment was better than after that. Different results were obtained by Tomiya et al. [13], where they found a significant decrease of retinol levels of breast milk at the end of their treatment targeting postpartum mothers given 1 capsule of Vitamin $A$ ( $p$ $<0.05$ ). Different time of consuming Vitamin $A$ by the subject can be the reason of the results. The study of Tomiya et al. 2015 [13] given the subjects 1 capsule of Vitamin $A$ at $6^{\text {th }}$ week after gave birth.

Furthermore, this study also found that there was no significant decrease of breast milk retinol levels in $\mathrm{C}$ group (fortified cooking oil group). This might be due to intervention of cooking oil every week that affected intake of Vitamin A of mothers. Sandjaja et al. found fortified cooking oil with Vitamin A could increase retinol levels of mothers' breast milk who breastfeed babies aged 6-12 months [9].

Decreasing of retinol levels of breast milk experienced by A group which significance 3 months after gave birth. It indicates that supplementation of Vitamin A did not affect breast milk retinol levels. Theoretically, it might happen because when mothers gave birth, it can trigger acute response that can increase $\mathrm{C}$-protein reactive levels. This is believed that it affects metabolism and transportation of Vitamin $A$ in our body, so that consumption of high dose of Vitamin $A$ after gave birth might not affect Vitamin A levels of breast milk [13].

The examination of breast milk retinol levels on the $1^{\text {st }}$ month after delivery (during intervention) shows that there has been a decrease in the proportion of mothers with normal categories of breast milk retinol. The largest decrease occurred in group D (around 40\%). This decline was probably due to the intervention in the form of education that did not directly affect levels of retinol in breast milk. It is contrast to other interventions, educational effect given to the subject requires time to be able to change the habit of consuming food sources of Vitamin A which is expected to affect the retinol levels of breast milk.

At the end of the study, it can be seen that the proportion of breast milk retinol levels in the normal category has decreased (this occurred in all treatment groups). The highest percentage of subjects with normal breastfeeding retinol category was found in Group C 
while the lowest in Group A. However, the KruskalWallis test results showed no significant difference in the proportion of subjects with normal breastfeeding categories between the treatment groups before, during, and after intervention ( $p>0.05)$. Overall, it can be seen in Picture 1 that about 1 in 2 breastfeeding mothers experience vitamin A deficiency problems (breast milk retinol $<30 \mu \mathrm{g} / \mathrm{dl}$ ). Based on the $\mathrm{WHO}$, the problem of Vitamin A deficiency in breastfeeding mothers in this study area is included in the severe category of public health problems because the percentage is more than $25 \%$ [15].

\section{Conclusions}

It can be concluded that the intervention given to the subject had the same effect on retinol levels in breast milk. In this study, it was found that the administration of cooking oil fortified with 62 SI vitamin A and supplementation with 1 capsule of vitamin A tended to reduce the proportion of mothers with low retinol levels compared to supplementation with 2 capsules of vitamin $\mathrm{A}$ and nutrition education.

\section{References}

1. World Health Organization. Guideline: Vitamin A Supplementation in Postpartum Women. Geneva: World Health Organization; 2011.

2. Humphrey $\mathrm{JH}$, Agoestina $\mathrm{T}$, Wu L, Usman A, Nurachim $\mathrm{M}$, Subardja $\mathrm{D}$, et al. Impact of neonatal Vitamin A supplementation on infant morbidity and mortality. J Pediatr. 1996;128(4):489-96. https://doi.org/10.1016/s0022-3476(96)70359-1

PMid:8618182

3. Roy S, Islam A, Molla A, Akramuzzaman S, Jahan F, Fuchs G. Impact of a single megadose of Vitamin $A$ at delivery on breastmilk of mothers and morbidity of their infants. Eur $\mathrm{J}$ Clin Nutr. 1997;51(5):302-7. https://doi.org/10.1038/sj.ejcn.1600398 PMid:9152680

4. Klemm RDW, Labrique AB, Christian P, Rashid M, Shamim AA, Katz J, et al. Newborn Vitamin A supplementation reduced infant mortality in rural Bangladesh. Pediatrics. 2008;122(1):e243-50. https://doi.org/10.1542/peds.2007-3448

PMid:18595969

5. Rotondi MA, Khobzi N. Vitamin A supplementation and neonatal mortality in the developing world: A meta-regression of clusterrandomized trials. Bull World Health Organ. 2010;88(9):697702. https://doi.org/10.2471/blt.09.068080 PMid:20865075

6. Bhaskaram P, Balakrishna N. Effect of administration of 200 , 000 IU of Vitamin A to women within 24 hrs after delivery on response to OPV administered to the newborn. Indian Pediatr. 1998;35(3):217-22.

PMid:9707874

7. Kemenkes. Kementerian Kesehatan. Laporan Hasil Riset Kesehatan Dasar 2013. Jakarta: Kemenkes; 2013.

8. Dary O, Mora JO. Food fortification to reduce Vitamin Adeficiency: International Vitamin A consultative group recommendations. J Nutr. 2002;132 Suppl 9:2927S-33S. https://doi.org/10.1093/ jn/132.9.2927s

PMid:12221271

9. Sandjaja, Jus'at I, Jahari AB, Ifrad, Htet MK, Tilden RL, et al. Vitamin A-fortified cooking oil reduces Vitamin A deficiency in infants, young children and women: Results from a programme evaluation in Indonesia. Public Health Nutr. 2015;18(14):251122. https://doi.org/10.1017/s136898001400322x PMid:25591926

10. Stoltzfus RJ, Underwood B. Breast-milk Vitamin A as an indicator of the Vitamin A status of women and infants. Bull World Health Organ. 1995;73(5):703-11. PMid:8846497

11. Esposito M, Sakurai E, Lamounier JA, Teixeira RA, Bonomo E, da Silva CA, et al. Retinol and fat from breast milk of Brazilian mothers at high risk for food unsafe. Ann Public Health Res. 2017;4(3):1063-8.

12. Bezerra DS, de Araújo KF, Azevêdo GM, Dimenstein $R$. A randomized trial evaluating the effect of 2 regimens of maternal Vitamin A supplementation on breast milk retinol levels. J Hum Lact. 2010;6(2):148-56. https://doi. org/10.1177/0890334409356445

PMid:20110563

13. Tomiya MT, de Arruda IK, da Silva Diniz A, Santana RA, da Silveira KC, Andreto LM. The effect of Vitamin A supplementation with $400000 \mathrm{IU}$ vs $200000 \mathrm{IU}$ on retinol concentrations in the breast milk: A randomized clinical trial. Clin Nutr. 2015;36(1):1006. https://doi.org/10.1016/j.clnu.2015.11.018 PMid:26725194

14. Newman V. Vitamin A and Breastfeeding: A Comparison of Data form Developed and Developing Countries. San Diego, US: Wellstart International; 1993.

15. World Health Organization. Indicator for Assessing Vitamin A Deficiency and their Application in Monitoring and Evaluating Intervention Programmes. Geneva: World Health Organization; 1998. 